\title{
ネオリベラリズム社会に打ける マネジメント・イデオロギー
}

樫村愛子

「雇用の危機」の背景には、社会による資本 主義のコントロールの危機 (制度と理念の危機) がある。本論ではこれをマネジメント・イデオ ロギー (仏社会学) の観点から、11資本主義 の新たな精神」、(2)「ポスト全体主義」、(3)ストー リーテリング、(4)臨床社会学による企業組織分 析を考察し、さらに日本の企業経営と人材マネ ジメントの問題を分析する。

\section{1.「資本主義の新たな精神」}

ウェーバーにおける「資本主義の精神」の定 義は、「資本主義の論理にとっての目的性とは 異質であるものの、資本蓄積に好適な活動へ企 業家を鼓舞する倫理的動機の総体」であった。 これを参照し、ボルタンスキやシャペロ（1999） は、資本主義を「形式上は平和な手段による、 資本の無際限な蓄積という要求」と定義する。

ボルタンスキらは、資本主義の精神と資本主 義の批判の歴史を以下のように整理している。

まず、「第一の資本主義の精神」は、19世紀 末、ブルジョワという人物像と結びついた、家 族的資本主義の段階のものであり、「賭けや投 機、リスク、イノベーションを強調する一大絵 巻の英雄的要素を一身に体現」した。

第一の資本主義は、労働者の権利や生活を侵 害し、個人レベルでは解決できない社会問題を 生じさせた。批判はマルクス主義や社会主義(著 者らが言う「社会的批判」) が担う。
「第二の資本主義の精神」は、1930～60年代 のもので、取締役や管理職といった人物像を中 心に形作られ、大企業を中心とした資本主義の 段階のものである。第二の資本主義は、フォー ディズム的構成とその調整様式としてのケイン ズ主義的、福祉国家体制を構成する。第一の資 本主義と異なり、企業家は個人ではなく組織で あり、巨大企業の組織化と労働者の権利の拡大 が進んだ。

第二の資本主義も、また新たな問題を生じさ せた。今度は、組織や官僚制、福祉国家の負の 側面が 68 年の運動を契機に批判される。「社会 的批判」に代わって、（第一の資本主義の精神 の時にも現れた）個人的でアナーキーな「芸術 的批判」が復活する（著者は「芸術的批判」と 「社会的批判」は交互で現れるとする)。

「第三の資本主義の精神」は、1990年代、グロー バル企業と新たなテクノロジー、フォーディ ズムの原理やヒエラルキー組織の放棄、ネット ワークとしての新しい組織と呼応し、物理的· 精神的安全性を犠牲にしても、行為者の能動性 や仕事における相対的自律性を重視した。

第三の資本主義は、現在指摘されているよう に、格差の拡大、雇用の不安定化、社会の解体、 （私と公の）「結合主義的世界」の中での不平等 と搾取を生んでいる。しかし、これに対し「社 会的批判」は混迷している。「資本主義は栄え ているが、社会は滅びつつある」「資本主義の 批判の冬の時代」と著者らは指摘する。現代に 
おける批判の枯渇が資本主義の正統性の危機と 病理を生んでいるのである。

\section{2.「ポスト全体主義」体制}

ルゴフ（2002）は、現在を、「市場全体主義」、 「全体主義的自由主義」と位置づけ、「ポスト全 体主義」と名付けている。ルゴフは、アレント の全体主義の議論を参照する。

アレントは、全体主義を、永続的な不安定状 態を生み出し、たえず新たな目的を目指して常 に前に進むことのみが重要となる動的状態にお いて社会を維持するものとしていた。アレント によれば、全体主義は、＜歴史>（ボルシェヴィ キ）抢よびく自然>（ナチ）といった巨大な運 動の中へ人々を入らせ、人類はそれに仕えるも のとなり、そこではプロパガンダと組織化が機 能した。プロパガンダは虚構の世界を構築し、 人々は現実から切断される。組織化については、 権威的な原則、明白な限定可能なヒエラルキー 的原則が一切存在せず、媒介、権限、責任が一 切破壊され、人々は無定形状態にされる。例え ば、ナチでは、同職団体のレプリカである「前 面組織」（正式な党員ではない、党友やシンパ からなり、外界と党とのクッションの役割を担 う組織。ナチによってあらゆる社会組織は党に よって二重化された）が作られ、党員は、外部 世界や現実と直接対面できなくされた。

ルゴフは、現実的なものの機能不全を強調し

\section{PROFILE}

樫村愛子

(かしむらいこ)

愛知大学文学部社会学コース教授、

日本社会学理論学会理事

専門 : 社会学・精神分析
て実験的とされる経験を評価し生き残りと緊急 性の適応論理 (cf. ショック・ドクトリン) で人々 を駆り立てる現在の状況に「全体主義」との類 似性を見出し、「ポスト全体主義」と名付けた。 そして「全体主義」と「ポスト全体主義」の両 者の類似性を、「内部分裂の否認と拒否」に見 た。また、両者の差異については、「全体主義」 には、「一者」幻想、「大いなる知」（マルクス 主義等々)への従属、プロパガンダがあるが、「ポ ス卜全体主義」は、多元主義や多様性を主張し、 不確定性を推し進めるとした。しかし、「ポス 卜全体主義」は多元主義や差異への権利を謳つ てはいても、その内容と真に直面することは避 け、自律、創発性、多様性という名の下におい て諸個人を同じ鋳型に押し込める。また「ポス 卜全体主義」では、「全体主義」のように「法 則の統御」を主張せず、「生き残り論理」を主 張する。言説は非一貫的で、専門家の知を操作 し、コミュニケーションを手段として使う。コ ミュニケーションについては、対話や協議を賞 賛してはいても、一種の隠蔽を行うことによっ て、現実には対話や協議を不可能にし、交流の 象徽的次元を解体する。 


\section{3. ストーリーテリング}

サルモン（2007）は、「認知／知識／感情資 本主義」の文化的動員において、文化は「アテ ンション・エコノミー」と結合されることを指 摘する。また、マーケティングにおけるブラン ドの危機を、ブランドの飽和（ブランドは 1983 年から 2003 年にかけて 10 倍の 14 万件に増加） と不安定さ（評判を落とせば一気に失墜）に見、 「ストーリーテリング」が危機の出口になった とした。そして、現在のようなネットワーク型 組織（ex.アップル、スタバ、エンロン、ノキア、 グーグル等) において組織の意味は失われやす く、組織のアイデンティティは危機に陥りやす いゆえ、アイデンティティを物語によって構築 することとなる。ストーリーテリングは現実を 隠して、幻想を共有させる「新しいナラティヴ 秩序権力」である（cf. 樫村 2010）。

\section{4. 臨床社会学による企業組織分析}

現代では、管理の合理化により、リーダーシッ プではなく、組織そのものの支配が進みつつあ る。そこでは、一人のリーダーが個人の自我理 想にすり替わる（cf. フロイトの『集団心理学 と自我の分析』）のではなく、組織の全能性の イマジネール（幻想）が個人の自我理想にすり 替わることを、臨床社会学の企業組織分析にお いて、ド・ゴルジャックらが示した。

個人はグループの前で、解体の不安を示し、
グループに融合－退行傾向を示す。この時、不 安定な集団が、役割や制度をもち組織化される と、個人のアイデンティティ不安は軽減され、 退行は抑制される。しかし、現代では、組織が 流動的なため、個人の不安や退行は、集団の組 織化によって抑制されることはなく促進され続 ける。それゆえ、ストーリーテリングのような、 強力で抽象的であり病理的なマネジメント・イ デオロギーがこれを埋めにくる。彼らは、この ような企業を「TLTXタイプの企業」と呼び、 規律の見た目の不在、命令や決定の不在、規律 の脱人格化・脱領域化などをその特性とした。

同様に、自らのマクドナルド（以下マック） での労働体験を分析したヴェベール（2005）は、 「マックで働くことは職業である」というマッ クのスローガンを批判し、マックは伝統的なレ ストランの職業的アイデンティティを破壊し、 人々を多能的労働者、マニュアルでできる交換 可能な労働者にすることを指摘した。だからこ そ、逆説的に「マックの労働者はメチエー職業 だ」という虚構が語られる（=ストーリーテリ ング)。ヴェベールも、マックにおいて、リーダー シップや組織化を欠いた、労働者がバラバラな ままでの組織幻想への同一化が見られ、労働者 を病理に追い込む点を指摘している。 


\section{5. 日本の企業経営と 人材マネジメント}

（1）企業統治と人材マネジメントの変更— 「株主重視」と「成果主義」(宮本2014)

1990年代初頭、バブル崩壊以降、日本企業が 迫られた制度変革は、(1)企業統治と人材マネジ メント（HRM）の変革と、(2)「株主重視」と「成 果主義」であった。

1997 ～98年金融危機以降、金融機関の持ち 株比率が低下し、また、株式は時価評価とされ た。さらに、バブル崩壊後の株価の急激な下落 においても金融機関に保有されていた株式が放 出されて、安定株主比率と相互持ち合い比率が 低下し、代わって外国人持株比率が増大してい く。また、バブル崩壊後の企業収益の極度の悪 化が、経営の競争力に目を向けさせることにな る（1999日産危機、2000そごう危機。そこで のメインバンクによる救済の不可)。

こうして2000年以降、日本の企業統治は配 当重視に傾いていく。また2002年以降、経営 者報酬はこれまでの従業員給与との連動から、 企業収益との連動へと変化する。そして、企業 は執行役員制の導入を中心とした取締役会の改 革を行い、職責意識の明確化を進めた。

「経営の自律を守るための株主配当という大 義 (名目)」が最初は主張されていたが、大義 (名 目）は実質にすり替わっていく。

（2）M\&Aによる雇用と賃金の搾取（柴田2014）
1999年「第一回産業競争力会議」では、「過 剩設備、過剩雇用、過剩借り入れ」の供給構造 の改革が必要とされ、商法改正を通じた「選択 と集中」の促進は、「過㮃処理」の一つの方法 と指摘された。 M\&Aは増加し、1990年代半ば まで年平均 500 件だったのが、2013年には2,048 件となった。株式の時価総額をもとに買収が行 われるので、上場企業における株価の重要性が 高まった。株価を上げることは、買収防衛策で もあった。

株価を上げるためには、資本効率を上昇させ る必要があり、賃金が削減され、株主配分が増 加された。こうして大企業ほど非正規雇用を増 加させていった。

\section{（3）人材戦略の変化（宮本2014）}

成果主義の導入によって、業績悪化に対する 経営組織の変革が行われる。そこでは、コスト 削減と事業成果の向上が目指され、成果主義が 導入される。しかし、日本企業の人材マネジメ ントの本質は、仕事を通じた長期の能力形成で あり、この能力の評価のために職能資格制度を 考案（「能力主義賃金」by小池）していた。ま た、ホワイトカラーの能力評価の困難について は、経験の評価を重視し、自動的昇給で実質年 功制を取ってきた。それゆえ、成果主義との親 和性は欠如していた。

結果的に、成果主義は、結果主義と短期主義 の弊害を生む。そして長期雇用の維持と成果主 義の導入による「ハイブリッド型（新日本型） 
経営」(自由な市場経済としての「市場型」と、 調整された市場経済としての「組織型」の混合） の結果として、正規雇用の減少と非正規雇用の 増大が起きた。

\section{（4）成果主義の背景と効果（津崎ほか 2008）}

1980年代の米、1990年代の日本では、内部 組織の市場化が起こる。すなわち「ベンチマー キング」（労働者に自らの仕事が市場競争にさ らされていることを意識させる手法）が取られ た。成果主義賃金の導入は、2004年までに6割、 1,000 人以上の企業で 8 割なされ、組織に対する 市場原理の導入がなされたが、結果的には、組 織の効率性は低下した。結局のところ、成果主 義の目的は人件費抑制にあり、評価制度の不適 切な導入が労働者からの批判を浴びる。

\section{（5）人事管理論と日本的特殊性}

労務管理（ブルーカラー対象） $\rightarrow$ 人事労務管 理（PM、ホワイトカラー対象。身分的差別の 撤廃と機械化によるホワイトカラーの増加によ り、労務管理を包摂。労使対立をはらむ）－人 的資源管理（HRM、労資協調的であり、長谷 川1998によれば「組合潰しの経営」）の変遷（江 2003）の中で生まれた「人的資源管理（HRM）」 は、日本が高度成長期から 90 年代にかけて行っ てきた人事慣行と類似している。分業体制か曖 昧な日本の方が効率が高く、従業員のモチベー ションも高いこと（教育訓練投資と動機づけ） が米によって学習された（上林2011）ものが逆
輸入されたのである。HRMを経て、日本型経 営は、「新日本型経営」になっていく。

（7）キャリア教育とSHRM、PBL（問題解決 型学習)

キャリア教育について、鹿内（2014）は、「若 年者就職基礎能力」(厚生労働省 2004）には、「企 業が採用に当たって重視し、基礎的なものとし て比較的短期間の訓練により向上可能な能力」 （cf.「エンプロイアビリティ」）が挙げられ、「小 学校・中学校・高等学校 キャリア教育推進の 手引き」（2006）で、各教科の学習をキャリア 教育と関連づけることを提唱していることを教 育の手段化において批判する。

また、SHRMとPBLについて、小澤（2014） は、現在、「遅い選抜」に表象される長期的で OJT中心の人材育成は、機能不全であるとされ て、SHRM（戦略的人的資源管理、1980年代～）、 すなわち、企業環境や経営戦略に適合的な人事 戦略があり、それにはべストプラクティスがあ るという発想に代わりつつあることを指摘す る。そしてここでは、才能とされていたリーダー シップを「経験」が育てるという発想が取られ、 PBL 等チームによる教育実践が進められつつあ ることを批判する。

\section{まとめ}

資本主義は、自身のうちに正当性を持たない 運動であり、資本主義に人々をコミットさせる 
ための理念やそれによって形象される制度を必 要とするが、現在のネオリベラリズムは、すべ てを流動化させるため、困難である（=「資本 主義の新たな精神」の欠如)。それは、「ポスト 全体主義」体制や「ストーリーテリング」、組 織化を欠いた組織幻想によって埋められ、病理 的であり、現実を否認している。

日本企業は、バブル以降、株主の時価評価へ の変更により、メインバンクが失墜、株主重視 となり、M\&Aによってコスト削減し、賃金を 削減、非正規雇用を増大させた。しかし、人件 費抑制のために導入された成果主義は組織を破 壊し、組織をフォローする人材を過労に追い込 んでいる。「新日本型経営」は、日本的な人材 育成（動機づけ）を目指したアメリカからの逆 輸入版（心理主義、内面化をはらみ、日本型経 営が破たんした日本に逆輸入）としての「人的 資源管理（HRM)」を取り入れたものである。 さらに「戦略的人的資源管理 $(\mathrm{SHRM}) 」 に お ~$ いては、リーダーシップを経験によって育てよ うと、「キャリア教育」と「PBL」が推し進め られているが、企業論理の教育への浸透であり、 結果的には創造的な企業経営を阻害していくた ろう。

\section{参考文献}

Arendt, H., 1951, The Origin of Totalitarianism

Boltanski, L., Chiapello,E., 1999, Le nouvel esprit du capitalisme, Gallimard

上林憲雄、2011「人的資源管理パラダイムと日本型人事シス テム」『国民経済雑誌』203(2).

樫村愛子、2010「『もしドラ』のストーリーテリングとマネジ メントの社会学 $/$ 精神分析学」『現代思想』38(10).

江春華、2003「人的資源管理の生成と日本的経営」『現代社会 文化研究』26

Le Goff,J .-P., 2002, La démoctatie post-totalitaire, La Découverte

宮本光晴、2014『日本の企業統治と雇用制度のゆくえ』ナカ ニシヤ出版

小澤伸光、2014「HRMとキャリア教育」『駿河台経済論集』 23(2)

Salmon C., 2007, Storytelling, La Découverte

柴田努、2014「成長戦略とコーポレート・ガバナンス一日本 経済の構造変化と株主価値重視経営」『唯物論研究年誌』 19.

鹿内啓子、2014「キャリア教育の問題点とあり方」『北星学園 大学文学部北星論集』51(2).

津崎克彦ほか、2008「平成不況期の人的資源管理改革による 従業員意識の個人化：市場化する雇用関係」『一橋社会科 学』 4 .

Weber H., 2005, Du ketchup dans les veines, érès 